\title{
Kreative titler og deres betydning for samfunn, vitenskap og forfatter
}

\author{
Tittelen kan være avgjørende for en artikkels praktiske verdi. Jo dårligere innholdet er, desto mer arbeid bør \\ det legges i utforming av tittelen. Lange og komplekse titler gir nemlig inntrykk av at mange og vanskelige \\ problemstillinger er drøftet.
}

I Tidsskriftet nr. 2/2013 drøfter Petter Gjersvik kriteriene for en god tittel på en vitenskapelig artikkel (1). Lederen er skrevet fra redaktørens ståsted i et velansett tidsskrift med høy forkastelsesprosent på innkomne manuskripter. Med dagens flora av «on-line»-publikasjoner er det lett å skaffe seg en lang liste uten å måtte gå veien om den type tidsskrifter Gjersvik representerer. Tittelsetting kan da ha helt andre formål enn dem Gjersvik forfekter.

En lang publikasjonsliste er vesentlig for ansettelses- og bedømmelseskomiteer. Komiteene leser vanligvis ikke alle arbeider på en slik liste. Titlene er gjerne det eneste de leser, og derfor må det legges stort arbeid i utformingen av disse. De bør kanskje være utformet slik at komitemedlemmene ikke engang tenker på å lese artikkelen. Av dette følger at jo svakere innhold, desto mer arbeid må det legges i tittelen.

Litteraturen omkring dette viktige emne er ikke stor (2-6). En kort oppsummering kan derfor være på sin plass. Denne oppsummeringen er i det vesentlige bygd på tidligere fremstillinger $(5,6)$.

\section{Statistikkens loppemarked}

Gjersvik anbefaler korte titler, men ikke for korte (1). Dette er ikke alltid å anbefale. Lange og komplekse titler gir inntrykk av at mange og vanskelige problemstillinger er drøftet. Men tittelen må selvfølgelig være strengt vitenskapelig slik at den kan være hentet fra Cochrane-basens vokabular. Her er fraseord fra statistikkens loppemarked helt avgjørende. Ord som «randomisert», «dobbeltblind» og «prospektiv» må brukes så ofte som mulig. En annen vinner er «multilineær regresjonsanalyse». «Korrelasjon» er også svært anvendelig, i tillegg til «sjelden (eller hyppig) forekomst av» eller «manglende (hittil ukjent) assosiasjon mellom». Brukbart kan også være «foreløpig rapport» eller «et essensielt verktøy i evalueringen av».

Man bør også prøve å virke ærlig og gi uttrykk for at arbeidet ikke helt viste det man hadde forventet: «Manglende korrelasjon mellom» eller «en viktig negativ studie» eller forsøksvis «en hypotese til forklaring på manglende evne til å påvise».

\section{Tidlig grått hår}

Overraskende eller uventede assosiasjoner er gunstig. «Forekomsten av migrene hos menn med tidlig (før 40 års alder) utviklet grått hår» er et slikt eksempel. Slike studier gir grunnlag for en rekke oppfølgere, med gunstig resultat for lengden på publikasjonslisten. Den nevnte studie må utvides med et eget kontrollmateriale av ikke-gråhårede menn. Feltet kan så innsnevres til «migrene

\section{«Jo svakere innhold, desto mer arbeid må det legges i tittelen»}

hos blonde (eller andre hårfarger) menn med tidlig utviklet grått hår». Bare fantasien setter grenser for nye titler: «Forekomsten av migrene hos menn med tidlig grått hår og skallethet - nye observasjoner». Virkelig sus over det blir det hvis man så bringer inn nye variabler: «Korrelasjon mellom migrene og koronar hjertesykdom hos tidlig gråhårede menn - en randomisert, dobbeltblind, prospektiv studie over effekten av kaffe». På dette punkt i forskningskarrieren kan man starte med artikler med «en historisk oversikt» eller en metaanalyse.

Nye begreper gir tittelen økt verdi: «Korrelasjon mellom migrene, koronar hjertesykdom og grått hår hos menn under 40 år multilineær regresjonsanalyse viser manglende sammenheng med faktor $\mathrm{x} »$. Her kan faktor x være hva som helst. Neste artikkel bør da hete: «Manglende effekt av faktor $\mathrm{x}$ ved migrene og koronar hjertesykdom hos gråhårede menn - en hypotese».

Medisinske og politiske moteretninger bør utnyttes: «Migrene, koronar hjertesykdom og tidlig grått hår hos menn - en miljømessig sammenheng». Denne miljømessige sammenhengen kan da være faktor $\mathrm{x}$, vide supra. «Miljømessig» kan varieres med «korrelasjon med sosioøkonomiske faktorer», eventuelt «manglende korrelasjon med urbane og rurale livsstilsmønstre». Helse- politisk er alt som smaker av økonomiske vurderinger (sparing) og forklaringer på økt sykelighet og uførhet $(7,8)$ sikre vinnere. Alle studier bør avsluttes med en oversiktsartikkel med litteraturgjennomgang og dernest en historisk oversikt.

Av ovenstående fremgår at tittelen kan være meget avgjørende for en artikkels praktiske verdi, det vil si anseelse og ansettelse. Kreativ tittelsetting bidrar til ideer til nye prosjekter, flere «papers», økende prestisje, misunnelse fra kolleger, beundring fra ansettelseskomiteer - og raskere karriere.

\section{Ragnar Stien \\ ragnarstien@hotmail.com}

Ragnar Stien (f. 1938) er pensjonert nevrolog. Forfatter har fylt ut ICMJE-skjemaet og oppgir ingen interessekonflikter.

\section{Litteratur}

1. Gjersvik P. Dette er en god tittel. Tidsskr Nor Legeforen 2013; 133: 129

2. Davis PJ, Gregerman RI. Parse analysis: a new method for the evaluation of investigators' bibliographies. N Engl J Med 1969; 281: 989-90.

3. Johnstone FR. The true publication index. A measure of scientific endeavor. JAMA 1967; 202: 371.

4 Zuckerman HA. Patterns of name ordering among authors of scientific papers: a study of social symbolism and its ambiguity. Am J Sociol 1968; 74: 276-91.

5. Yankelowitz BY. How to write nifty titles for your papers. BMJ 1980; 281: 96.

6. Stien R. Publikasjonslister. Hvilken symbolverdi har de enkelte artiklers tittel. Axonet 2002; nr. 3: $20-1$.

7. Stien R. Skivepris - et forsøk på å bedre økonomistyringen i norske sykehus. Tidsskr Nor Lægeforen 2001; 121: 1132.

8. Stien R. Antall levende tanters betydning for helsetilstanden i den norske befolkning. Tidsskr Nor Lægeforen 1997; 117: 1206.

Mottatt 25.1.2013 og godkjent 3.2. 2013. Medisinsk redaktør Siri Lunde.

Publisert først på nett. 